\title{
WETLANDS PRESERVATION AND WATERFOWL RESEARCH
}

All Canadian hunters must now buy a two dollar Canada Migratory Game Bird Hunting Permit. By doing this they are, according to the permit, "contributing to Canada's expanding program of wetlands preservation and waterfowl research and management."

The federal government should be commended for announeing and actively embarking on definite wildlife programs. First, Canada's Wildlife Policy and Program was tabled in the House of Commons in April, 1966, committing Canada to an accelerating program which may spend $\$ 60$ million in the next ten years. Much of this will be spent on "the preservation of major waterfowl production areas by leasing, to prevent draining, filling, or burning of the surrounding vegetation." Some money will also be spent on research and scholarships to encourage the training of more wildlife biologists.

Second, the Canada Migratory Game Bird Hunting Permit-expected to bring in some $\$ 700,000$ in $1966-$ will allow the Canadian Wildlife Service to set up an annual survey of hunting pressure. The results of the survey will tell how many people hunt migratory birds, where and when they hunt, how many birds are killed and where and when these birds are killed. The Canadian Wildlife Service explains, "only through sound management, based on knowledge obtained with your (the hunters') cooperation, can we hope to ensure migratory bird hunting for the future."

Migratory birds are a national resource and our federal government must, in so far as it can, ensure the future success of these birds. It must deal with the governments of other countries to see for example that they ensure the safety of our birds during the winter months. There has been a strong feeling that the Canadian Government has not been active enough in dealing with the provincial governments and with foreign governments regarding our waterfowl resource. Why, for instance, should U.S. biologists contribute so much to spring and summer duck surveys while Canada takes no part in winterground duck surveys? Why do American hunters through Ducks Unlimited do so much about making inventories and preserving our wetlands while we do so little? If the Americans count and pay for the raising of ducks in Canada then it may seem reasonable that the Americans should determine how many ducks could, fairly, be shot in Canada.

Today wetlands are threatened by the demand for greater food production and the ease with which land may be levelled or drained. The need for food will continue to increase as transportation problems are solved and populations increase. In spite of our record-breaking crop, the amount of food per person in the world decreased appreciably again this year. The land, however, should not be solely under the jurisdiction of agriculture. It has, for instance, to produce wildlife and this resource is of real value to the nation. It is estimated that the U.S. sportsmen spent over four billion dollars to hunt and fish in 1965. Others who do not hunt or fish probably spent even more in the pursuit of wildlife.

The preserving of wetlands is an urgent problem needing prompt and vigorous action. Hunters by buying hunting permits are helping to solve the problem. The Canadian government should also make it possible for hunters and non-hunters to contribute to the preservation of our wetlands by asking them to buy wildlife or wetland stamps and by accepting the gifts, bequests and donations of all those wishing to contribute to programs of land acquisition for wildlife. We must spend money now if we want to have migratory birds in the future. 